\title{
INFLUENCE OF ANTIBIOTICS ON EMBRYOGENIC TISSUE AND AGROBACTERIUM TUMEFACIENS SUPPRESSION IN SOYBEAN GENETIC TRANSFORMATION ( $\left.{ }^{1}\right)$
}

\author{
BEATRIZ WIEBKE $\left({ }^{2,3}\right)$; FABRICIO FERREIRA $\left({ }^{3}\right)$; GIANCARLO PASQUALI $\left({ }^{4}\right)$; \\ MARIA HELENA BODANESE-ZANETTINI $\left({ }^{2}\right)$; ANNETTE DROSTE $\left({ }^{3}\right)$
}

\begin{abstract}
The influence of different antibiotic treatments in soybean genetic transformation was evaluated. First, an assay was performed to verify how different antibiotic treatments affect soybean embryogenic tissues. The effect of carbenicillin at $500 \mathrm{mg} \mathrm{L}^{-1}$ was genotype-dependent. This antibiotic did not affect embryo survival of cv. IAS5, but a three-fold increase of embryo proliferation was observed for cv. Bragg, when compared to the control. On the other hand, cefotaxime at 350 and $500 \mathrm{mg} \mathrm{L}^{-1}$ caused death of embryogenic tissues of both cultivars. Finally, the association of cefotaxime $\left(250 \mathrm{mg} \mathrm{L}^{-1}\right)+$ vancomycin $\left(250 \mathrm{mg} \mathrm{L}^{-1}\right)$ did not affect negatively the somatic embryos of tested cultivars until 63 days of treatment. Thereafter, a second experiment was carried out to determine the efficacy of different antibiotic treatments in suppressing LBA4404 Agrobacterium tumefaciens strain in genetic transformation. On tissue culture conditions, carbenicillin at 500 and $1000 \mathrm{mg} \mathrm{L}^{-1}$ was not active against Agrobacterium. On the other hand, treatments with cefotaxime at 350 and $500 \mathrm{mg} \mathrm{L}^{-1}$, and cefotaxime + vancomycin efficiently suppressed Agrobacterium during 49 days. Data of both experiments suggested cefotaxime + vancomycin for 49-63 days as the most appropriate treatment. This is the first work reporting the effect of antibiotics on soybean tissues. By identifying an antibiotic combination that suppressed $A$. tumefaciens with minimal phytotoxic effects, we are able to recommend it for improvement of soybean Agrobacterium-mediated transformation procedure.
\end{abstract}

Key words: Agrobacterium tumefaciens, carbenicillin, cefotaxime, genetic transformation, Glycine max, vancomycin.

\section{RESUMO}

\section{INFLUÊNCIA DE ANTIBIÓTICOS SOBRE O TECIDO EMBRIOGÊNICO E A SUPRESSÃO DE AGROBACTERIUM TUMEFACIENS NA TRANSFORMAÇÃO GENÉTICA DE SOJA}

Foi avaliada a influência de diferentes tratamentos com antibióticos durante a transformação genética de soja. Inicialmente, desenvolveu-se um estudo para identificar como diferentes tratamentos com antibióticos afetam o tecido embriogênico da soja. O efeito da carbenicilina a $500 \mathrm{mg} \mathrm{L}^{-1}$ foi genótipodependente. Esse antibiótico não afetou a sobrevivência dos embriões da cv. IAS5, enquanto a proliferação dos embriões da cv. Bragg foi três vezes maior quando comparada com o controle. Por outro lado, cefotaxima, a 350 e $500 \mathrm{mg} \mathrm{L}^{-1}$, causou a morte dos tecidos embriogênicos de ambas as cultivares. Por fim, a associação de cefotaxima $\left(250 \mathrm{mg} \mathrm{L}^{-1}\right)+$ vancomicina $\left(250 \mathrm{mg} \mathrm{L}^{-1}\right)$ não afetou negativamente os

(1) Received for publication in January 26, 2006 and approved in August 8, 2006.

( $\left.{ }^{2}\right)$ Departamento de Genética, Instituto de Biociências, Universidade Federal do Rio Grande do Sul, Caixa Postal 15053, 91501-970 Porto Alegre (RS), Brasil. E-mail: strohm@sinos.net, maria.zanettini@ufrgs.br.

$\left({ }^{3}\right)$ Setor de Botânica, Ciências da Saúde, Universidade do Vale do Rio dos Sinos, Caixa Postal 275, 93022-000 São Leopoldo (RS), Brasil. E-mail: fabferreira@pop.com.br, adroste@unisinos.br. ${ }^{*}$ Corresponding author.

$\left({ }^{4}\right)$ Centro de Biotecnologia do Estado do Rio Grande do Sul e Departamento de Biologia Molecular e Biotecnologia, Instituto de Biociências, Universidade Federal do Rio Grande do Sul, Caixa Postal 15005, 91501-970 Porto Alegre (RS), Brasil. E-mail: pasquali@cbiot.ufrgs.br. 
embriões somáticos das cultivares testadas durante os 63 dias de tratamento. Posteriormente, foi realizado um segundo experimento para determinar a eficiência de diferentes tratamentos com antibióticos na supressão da linhagem LBA4404 de Agrobacterium tumefaciens durante a transformação genética. Nas condições da cultura, a carbenicilina, a 500 e $1000 \mathrm{mg} \mathrm{L}^{-1}$, não foi eficiente para a supressão de Agrobacterium. Por outro lado, os tratamentos com cefotaxima, 350 e $500 \mathrm{mg} \mathrm{L}^{-1}$, ou cefotaxima + vancomicina suprimiram eficientemente Agrobacterium após 49 dias. Os dados dos dois experimentos sugerem a cefotaxima + vancomicina por 49-63 dias como o tratamento mais apropriado. Esse é o primeiro registro do efeito de antibióticos sobre tecidos de soja. Foi identificada uma combinação de antibióticos que suprimiram $A$. tumefaciens com efeitos fitotóxicos mínimos, podendo ser recomendada para a otimização do método de transformação genética de soja mediada por Agrobacterium.

Palavras-chave: Agrobacterium tumefaciens, carbenicilina, cefotaxima, transformação genética, Glycine max, vancomicina.

\section{INTRODUCTION}

Agrobacterium-mediated transformation is one of the well-established techniques for introducing foreign DNA into plant tissues (HORSCH, 1985; STAFFORD, 2000). The procedure involves the infection of explants by co-cultivation with disarmed Agrobacterium carrying a gene of interest. However, after transfering the genetic information, bacteria suppression is necessary, since their presence can interfere with growth and development of transformed plant cells or, even, cause the death of the cultures (COOKe et al., 1992; Mayolo et al., 2003). For this purpose, plant tissues are usually transferred to medium containing antibiotics. Carbenicillin, cefotaxime and vancomycin are antibiotics widely used to suppress Agrobacterium after genetic transformation. There are many reports concerning the most appropriate antibiotic treatment (type, concentration, period) to effectively suppress Agrobacterium from target plant tissues of many species (Hammerschlag et al., 1997; NAuerby et al., 1997; CHeng et al., 1998; TANG et al., 2000; ЕstopÀ et al., 2001; MAYOLO et al., 2003). However, results are very diverse, depending on several factors including Agrobacterium strain, density of bacterial suspension, incubation and co-culture lenght, type and concentration of bactericidal agents, and duration of antibiotic treatment.

One of the main purposes in our laboratory is to develop a genetic transformation procedure for Brazilian commercial soybean cultivars, aiming to introduce genes of interest for their improvement. Droste et al. (2000) described a basic method for Agrobacterium transformation of proliferating soybean somatic embryos. In this procedure, tungsten particle bombardment was used prior to Agrobacterium inoculation to cause microwounds on somatic embryo clusters, thereby enhancing bacteria attachment and gene transfer to plant cells due to chemical signals from the wounded tissues (HoOYKAAs et al., 1991). Although an expressive transient activity was detected, all embryogenic tissues submitted to the transformation procedure died during the antibiotic treatment. Thus far, no reports on stable transformation and recovery of fertile transgenic soybean plants using this method were published. The obstacle for the obtainment of stable transformants may have been the sensitivity of soybean somatic embryos to the antibiotic treatment.

The level of the required antibiotic for Agrobacterium suppression is usually high and may interfere with the plant cultures by either inhibiting or promoting explant growth and regeneration. Plant sensitivity to antibiotics is species-specific and depends on a large extent on plant growth conditions (Lin et al., 1995; NAUERBY et al., 1997; Estopà et al, 2001; Minaljevic et al. 2001; Bhau and WaKhlu, 2001; Yu et al., 2001; SiLva et al., 2003; MAYolo et al., 2003).

The goal of this study was to evaluate how different antibiotic treatments affect soybean embryogenic tissues and to determine their efficacy in suppressing A. tumefaciens in Agrobacterium-mediated genetic transformation. This is the first work reporting the effect of antibiotics on soybean tissues.

\section{MATERIALS AND METHODS}

\section{Plant material and culture conditions}

Two soybean cultivars, Bragg and IAS5, were used in this study due to their high response to inoculation with wild strains of $A$. tumefaciens (DROSTE et al., 1994) and their capability to react to in vitro culture conditions (Droste et al., 2001). Bragg is a North American-adapted cultivar, commonly used in genetic improvement programs, while IAS5 is a Brazilian cultivar indicated for commercial cropping in Brazil (Costamillan and Bertagnolli, 2004).

Pods with immature seeds (3-4 mm), harvested from field-grown plants, were surface sterilized by $1 \mathrm{~min}$ immersion in $70 \%$ ethanol, followed by $15 \mathrm{~min}$ in $4 \%$ 
sodium hypochlorite containing Tween-20. After three rinses in autoclaved distilled water, the immature seeds were excised and the cotyledons removed. To induce the somatic embryo formation, each cotyledon was placed with the abaxial side facing the modified D40 medium (BAILEY et al., 1993), which contains MS salts (Murashige and SKoog, 1962), B5 vitamins (GAmborg et al., 1968), $40 \mathrm{mg} \mathrm{L}^{-1}$ 2,4-D, 3\% sucrose, $0.3 \%$ Phytagel $^{\mathrm{TM}}$, $\mathrm{pH} 7.0$ (prior to autoclaving). Twenty cotyledons were placed in each plate. After 40 days on D40 medium, the cotyledons were transferred to D20 medium (D40 medium containing $20 \mathrm{mg} \mathrm{L}^{-1}$ 2,4-D, 3\% sucrose, $\mathrm{pH}$ 6.4; Wright et al., 1991). Fourteen days later, proliferative embryogenic tissues were separated and proliferated in D20 medium, with subcultures every 14 days. During the experiment, the cultures were maintained at $26 \pm 1^{\circ} \mathrm{C}$ with $16 / 8 \mathrm{~h}$ light/dark at a light intensity of $22.5 \mathrm{mEm}^{-2} \mathrm{~s}^{-1}$.

\section{Agrobacterium strain}

Agrobacterium tumefaciens LBA4404 harboring the superbinary plasmid pTOK233 (HIEI et al., 1994) were used for the transformation experiment. Fourty-eight hours prior to transformation procedure, isolated colonies were grown in LB liquid medium according to DROSTE et al. (2000) and ressuspended to an $\mathrm{OD}_{600 \mathrm{~nm}}$ of 0.3 .

\section{Antibiotics}

The antibiotics cefotaxime (Claforan ${ }^{\circledR}$, Laboratório Hoechst Marion Roussel S/A, Brazil), carbenicillin (Sigma) and vancomycin (Vanclomin ${ }^{\circledR}$, Teuto Brasileiro, Brazil) were dissolved in water, filtersterilized and stored at $-20^{\circ} \mathrm{C}$. Later, they were added to the autoclaved and partially cooled medium.

\section{Experimental treatments}

\section{Effects of antibiotics on somatic embryogenic tissues}

After four months on proliferation D20 medium, untransformed embryogenic clusters (around $0.67 \mathrm{mg}$ and $2 \mathrm{~mm}$ in diameter each) were transferred to D20 medium supplemented with antibiotics. Four treatments were tested: (1) $350 \mathrm{mg} \mathrm{L}^{-1}$ cefotaxime, (2) $500 \mathrm{mg} \mathrm{L}^{-1}$ cefotaxime, (3) $500 \mathrm{mg} \mathrm{L}^{-1}$ carbenicillin and (4) $250 \mathrm{mg} \mathrm{L}^{-1}$ cefotaxime $+250 \mathrm{mg} \mathrm{L}^{-1}$ vancomycin. Medium without antibiotics was used as control. The tissues were maintained under these conditions during 98 days, with subcultures every 14 days. The number of embryogenic clusters analyzed per cultivar/treatment is presented in Table 1.

Every 14 days embryogenic clusters were classified according to their extension of necrosis: (1) cluster without necrosis, (2) less than half cluster with necrosis, (3) half cluster with necrosis, (4) more than half cluster with necrosis and (5) entire cluster with necrosis. The extension of necrosis per treatment and cultivar was compared by Monte Carlo non-parametric statistical analysis.

At the end of the experiment, the percentage of surviving embryogenic clusters per treatment was evaluated and statistically analyzed by classical chisquare test. The residuals (observed value minus expected value) for each cell of table were individually analyzed in case the $\left.\right|^{2}$ value was statistically significant at $\langle=0.05$. Proliferating green tissue of each cluster was selected and individually weighted. Differences on the weight of surviving tissues among cultivars were analyzed by Mann-Whitney test and among treatments by Kruskal Wallis non-parametric analysis of variance. Pairwise multiple comparisons of ranked data were performed to compare treatments. Results of all statistical analyses with SPSS (C) statistical software for Windows were considered significant at $\mathrm{P}<0.05$.

\section{Effects of antibiotics on Agrobacterium}

Embryogenic tissues of cv. Bragg, proliferated during six months on D20 medium, were submitted to the integrated bombardment and Agrobacterium transformation system according to DROSTE et al. (2000) with modifications. Bombardments were performed using a Particle Inflow Gun - PIG (FINER et al., 1992). Twenty-five $\mu \Lambda$ of tungsten particles suspended in sterile distilled water were mixed with $25 \mu \Lambda \mathrm{CaCl}_{2}(2.5$ $\mathrm{M})$ and $15 \mu \Lambda$ spermidin $(0.1 \mathrm{M})$. After $5 \mathrm{~min}$ on ice, 45 $\mu \Lambda$ of the supernatant were removed. Each dish was bombarded once, with $2 \mu \Lambda$ of the pellet mixture. Following the bombardment, the clusters were inoculated and incubated for $20 \mathrm{~min}$ in the bacterial suspension. Then, the inoculated explants were blotted on sterile filter paper and co-cultured for $48 \mathrm{~h}$ on D20 medium supplemented with $100 \mu \mathrm{M}$ acetosyringone. After this period, the tissues were washed in sterile distilled water, blotted on sterile filter paper and transferred to D20 medium containing antibiotics. Five treatments were tested: (1) $350 \mathrm{mg} \mathrm{L}^{-1}$ cefotaxime, (2) $500 \mathrm{mg} \mathrm{L}^{-1}$ cefotaxime, (3) $500 \mathrm{mg} \mathrm{L}^{-1}$ carbenicillin, (4) $1000 \mathrm{mg} \mathrm{L}^{-1}$ carbenicillin and (5) $250 \mathrm{mg} \mathrm{L}^{-1}$ cefotaxime $+250 \mathrm{mg} \mathrm{L}^{-1}$ vancomycin. Thirty clusters $(0.67 \mathrm{mg}$ each) were cultured for each treatment, 10 clusters in each dish. Embryogenic clusters were transferred to fresh medium every 14 days.

Clusters were individually evaluated for the presence of bacteria at seven days intervals under a stereoscopic microscope and data were compared by Kruskal Wallis non-parametric analysis of variance. Pairwise multiple comparisons of ranked data were performed to compare treatments. 
Intending to observe the possible recurrence of bacteria after different periods on antibiotic containing medium, embryogenic clusters of one dish/treatment were transferred to D20 medium without antibiotics after 35, 49 and 63 days, respectively. Data were statistically compared by Fisher non-parametric analysis. Results of all statistical analyses with SPSS $($ ) statistical software for Windows were considered significant at $\mathrm{P}<0.05$.

\section{RESULTS AND DISCUSSION}

\section{Effects of antibiotics on somatic embryogenic tissues}

Untransformed embryogenic clusters were cultured on medium supplemented with antibiotics for 98 days. Different concentrations of antibiotics commonly used in transformation experiments were tested. Embryogenic clusters cultured on antibioticfree medium were used as control.

To evaluate the effect of treatment length on plant tissues, the embryogenic clusters were individually analyzed for the extension of necrosis every 14 days. Necrosis was first observed after 35 days, gradually increasing in extension along the time. Although necrosis was also observed on embryogenic clusters cultured on antibiotic-free medium (control), its extension never exceeded $25 \%$ of the cluster. No significant differences among treatments and cultivars were detected after 35 and 49 days of culture. However, after 63 days, necrosis extension varied significantly among treatments within cv. Bragg (Table 1). For this cultivar, the frequency of embryogenic clusters without necrosis (class -) was higher for the control. A significant higher number of clusters presenting necrosis on less than half of their extension (class + ) were obtained on treatments with carbenicillin and cefotaxime + vancomycin. Higher frequencies of clusters showing necrosis on half or more than half of their extension (class ++ and +++ ) were observed for cefotaxime at 350 and $500 \mathrm{mg} \mathrm{L}^{-1}$. These findings indicated that, after 63 days antibiotic treatment, cefotaxime alone in both tested concentrations is more toxic to Bragg embryogenic tissues than other antibiotics. The data obtained for $\mathrm{cv}$. IAS5 showed a similar tendency than those observed for $\mathrm{cv}$. Bragg. However, differences among treatments were not detected by the statistical analysis.

After 77 days, for most treatments a substantial increase on necrosis extension could be observed, especially for cv. IAS5. An exception was the treatment with carbenicillin, which only presented negative effects on clusters of cv. IAS5 in the last week. Therefore, except for carbenicillin, it would be desirable that antibiotic treatment did not exceed more than 63 days.
After 98 days on medium with antibiotics, the percentage of surviving embryogenic clusters per treatment was analyzed and the proliferative green tissues evaluated for their weight. Significant differences among cultivars were detected, indicating that IAS5 was more sensitive to antibiotics than Bragg. Data are presented on table 2. For cv. IAS5, the lowest percentage and weight of surviving clusters were observed on cultures containing cefotaxime + vancomycin. On the other hand, this cultivar presented higher percentages of surviving embryogenic clusters and green tissue weight on media without antibiotic (control) or supplemented with $500 \mathrm{mg} \mathrm{L}^{-1}$ carbenicillin. For $\mathrm{cv}$. Bragg, the lowest percentages of surviving clusters were obtained using $500 \mathrm{mg} \mathrm{L}^{-1}$ cefotaxime or cefotaxime + vancomycin, whereas clusters cultured on other treatments presented significant higher survival percentages. Green tissues obtained on carbenicillin containing medium presented significant higher weight when compared with other treatments, achieving three times the weight of green tissues submitted to the control regime. Although the mean weight of green tissues obtained in the additional treatments (cefotaxime $350 \mathrm{mg} \mathrm{L}^{-1}$, cefotaxime $500 \mathrm{mg} \mathrm{L}^{-1}$, cefotaxime + vancomycin and control) did not differ significantly, a direct association between the percentages of surviving clusters and their weight could also be observed for cv. Bragg.

Despite the importance of antibiotics during Agrobacterium-mediated transformation, no reports about the effect of these drugs on grain legume tissues, especially soybean, are available. Direct comparisons are difficult, because antibiotic effects differ according to plant species, type of explant and culture system.

The addition of $500 \mathrm{mg} \mathrm{L}^{-1}$ carbenicillin to culture medium did not affect tissues of cv. IAS5, whereas proliferation of embryos of $\mathrm{cv}$. Bragg was significantly enhanced. This antibiotic was previously reported as efficiently inducing somatic embryo formation of Dianthus cultivars at $500 \mathrm{mg} \mathrm{L}^{-1}$ (NAKANO and MII, 1993). The mechanism of the stimulatory effect of carbenicillin is based on the structural composition of this antibiotic. Holford and Newbury (1992) showed that phenylacetic acid, a naturally occurring auxin, were one of the breakdown products of carbenicillin. This is in agreement with previous observations that high levels of auxin are required for soybean somatic embryos induction and proliferation (RANCH et al., 1985).

On the other hand, a detrimental effect of carbenicillin has been found on embryogenesis of most studied species. Decrease on embryo production in the presence of carbenicillin was observed for Picea 
sitchensis at $500 \mathrm{mg} \mathrm{L}^{-1}$ (SARMA et al., 1995), Juglans regia at $100-1000 \mathrm{mg} \mathrm{L}^{-1}$ (TANG et al., 2000), Picea omorika at $500 \mathrm{mg} \mathrm{L}^{-1}$ (Minaljevic et al., 2001), Carica papaya at 375 and $500 \mathrm{mg} \mathrm{L}^{-1}$ (Yu et al., 2001) and Theobroma cacao at 100-300 $\mathrm{mg} \mathrm{L}^{-1}$ (MAYOLO et al., 2003). LIN et al. (1995) argued that, besides the breakdown products, other factors are involved in producing the auxin effects of carbenicillin, which turn the influence of this antibiotic on plant tissue culture more complex.

Analyzing the effect of cefotaxime on soybean somatic embryos, it was clearly observed that this antibiotic, regardless of concentrations, caused death of a considerable tissue extension, thereby reducing embryo proliferation capacity. This result can explain the fail on obtention of stable transformed tissues by Droste et al. (2000), who submitted the embryo clusters to $350 \mathrm{mg} \mathrm{L}^{-1}$ cefotaxime, for 90 days. Effects of this drug on embryogenesis of other species vary according to antibiotic concentration. In Juglans regia, concentrations lower than $500 \mathrm{mg} \mathrm{L}^{-1}$ determined slight reduction of embryo production, whereas at $1000 \mathrm{mg} \mathrm{L}^{-1}$ cefotaxime the effect was significantly inibitory (TANG et al., 2000). Embryogenesis of Carica papaya was enhanced by $250 \mathrm{mg} \mathrm{L}^{-1}$ and reduced by $125 \mathrm{mg} \mathrm{L}^{-1}$ cefotaxime, whereas no effects were observed at 375 and $500 \mathrm{mg} \mathrm{L}^{-1}$ (Yu et al., 2001). Cefotaxime enhanced embryo production of Theobroma cacao at $150 \mathrm{mg} \mathrm{L}^{-1}$, while negative effects were observed at other concentrations tested (MAYOLO et al., 2003). Additionally, this antibiotic was reported as effectively promoting somatic embryogenesis of Dianthus cultivars at $100-500 \mathrm{mg} \mathrm{L}^{-1}$ (NAKANO and MII, 1993) and Triticum aestivum at $60-100 \mathrm{mg} \mathrm{L}^{-1}$ (Mathias and Boyd, 1986). But, species such as Picea sitchensis (SARMA et al., 1995) and P. omorika (MiHALJEviC et al., 2001) were not affected by cefotaxime treatment.

Table 1. Percentage of embryogenic clusters of two soybean cultivars in each necrosis extention class after 63 days of different antibiotic treatments

\begin{tabular}{|c|c|c|c|c|c|c|c|c|c|c|c|c|c|}
\hline \multirow{3}{*}{ Antibiotics } & \multirow{3}{*}{ Concentrations } & \multicolumn{6}{|c|}{ IAS5 } & \multicolumn{6}{|c|}{ Bragg } \\
\hline & & \multirow{2}{*}{$\begin{array}{c}\text { Number of } \\
\text { embryogenic } \\
\text { clusters }\end{array}$} & \multicolumn{5}{|c|}{ Necrosis extension $\left({ }^{1}\right)$} & \multirow{2}{*}{$\begin{array}{c}\text { Number of } \\
\text { embryogenic } \\
\text { clusters }\end{array}$} & \multicolumn{5}{|c|}{ Necrosis extension } \\
\hline & & & - & + & ++ & +++ & ++++ & & - & + & ++ & ++++ & ++++ \\
\hline & $\mathrm{mg} \mathrm{L}^{-1}$ & &  & 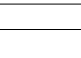 & - \% & & $\bar{u}$ & & & & $\%$ & & \\
\hline Cefotaxime & 350 & 75 & 0.0 & 38.6 & 10.7 & 50.7 & 0.0 & 75 & 1.3 & 61.3 & $6.7^{*}$ & $30.7^{*}$ & 0.0 \\
\hline Cefotaxime & 500 & 75 & 6.7 & 69.3 & 5.3 & 18.7 & 0.0 & 71 & 2.8 & 63.0 & $7.0^{*}$ & $26.8^{*}$ & 0.0 \\
\hline Carbenicillin & 500 & 67 & 17.9 & 77.6 & 1.5 & 1.5 & 1.5 & 56 & 3.6 & $92.9 *$ & 0.0 & 3.6 & 0.0 \\
\hline $\begin{array}{l}\text { Cefotaxime } \\
+ \text { vancomycin }\end{array}$ & $250+250$ & 75 & 0.0 & 38.8 & 6.6 & 54.6 & 0.0 & 75 & 1.3 & $82.7^{*}$ & 0.0 & 16.0 & 0.0 \\
\hline Control & - & 69 & 17.4 & 52.2 & 4.3 & 26.1 & 0.0 & 63 & $15.9^{*}$ & 73.0 & 1.6 & 9.5 & 0.0 \\
\hline
\end{tabular}

$\left({ }^{1}\right)(-)$ cluster without necrosis; $(+)$ less than half cluster with necrosis; $(++)$ half cluster with necrosis; $(+++)$ more than half cluster with necrosis; $(++++)$ entire cluster with necrosis.

* Monte Carlo non-parametric analysis: significantly different at 0.05 (same column).

Table 2. Survival and weight of proliferative embryogenic clusters of two soybean cultivars after 98 days of different antibiotic treatments

\begin{tabular}{|c|c|c|c|c|c|c|c|}
\hline \multirow[b]{2}{*}{ Antibiotics } & \multirow[b]{2}{*}{ Concentrations } & \multicolumn{3}{|l|}{ IAS5 } & \multicolumn{3}{|c|}{ Bragg } \\
\hline & & $\begin{array}{c}\text { Number of } \\
\text { embryogenic } \\
\text { clusters }\end{array}$ & $\begin{array}{c}\text { Survival } \\
\text { clusters }\left({ }^{1}\right)\end{array}$ & $\begin{array}{c}\text { Weight of } \\
\text { cluster } \\
\left(\text { mean } \pm \text { SD) }\left({ }^{2}\right)\right.\end{array}$ & $\begin{array}{l}\text { Number of } \\
\text { embryogenic } \\
\text { clusters }\end{array}$ & $\begin{array}{c}\text { Survival } \\
\text { clusters }\left({ }^{1}\right)\end{array}$ & $\begin{array}{c}\text { Weight of } \\
\text { cluster } \\
(\text { mean } \pm \text { SD) }\end{array}$ \\
\hline & $\mathrm{mg} \mathrm{L}^{-1}$ & & $\%$ & $\mathrm{mg}$ & & $\%$ & $\mathrm{mg}$ \\
\hline Cefotaxime & 350 & 75 & 68.0 & $0.94 \pm 1.06 \mathrm{~b}$ & 75 & $98.6 \uparrow$ & $4.29 \pm 3.41 \mathrm{~b}$ \\
\hline Cefotaxime & 500 & 75 & 73.3 & $1.33 \pm 1.38 \mathrm{~b}$ & 71 & $85.9 \downarrow$ & $3.59 \pm 4.08 \mathrm{~b}$ \\
\hline Carbenicillin & 500 & 67 & $74.6 \uparrow$ & $4.84 \pm 3.97 \mathrm{a}$ & 56 & $100 \uparrow$ & $13.84 \pm 9.11 \mathrm{a}$ \\
\hline $\begin{array}{l}\text { Cefotaxime } \\
+ \text { vancomycin }\end{array}$ & $250+250$ & 75 & $30.6 \downarrow$ & $0.27 \pm 0.22 \mathrm{c}$ & 75 & $82.7 \downarrow$ & $2.89 \pm 3 \mathrm{~b}$ \\
\hline Control & - & 69 & $78.3 \uparrow$ & $5.62 \pm 5.78 \mathrm{a}$ & 63 & $98.4 \uparrow$ & $4.64 \pm 4.34 \mathrm{~b}$ \\
\hline
\end{tabular}

( ${ }^{1}$ Chi-square residual test: significant differences at 0.05 . “ $\uparrow$ ” indicates higher and “ $\downarrow$ " lower percentages of survival in relation to the expected values.

$\left({ }^{2}\right)$ Multiple comparisons test: different letters in the same column indicate significant differences at 0.05 . 
The chemical structure of cefotaxime does not readily suggest a breakdown product with auxin-like properties (HOLFORD and NEWBURY, 1992) and a different mode of action may have to be sought. It is possible that metabolites, with plant growth regulatory activity, generated from cefotaxime by plant esterases, may be responsible for the effects observed on tissues of some species (MATHIAS and BOYD, 1986; SARMA et al., 1995).

Culture medium containing cefotaxime + vancomycin did not affect soybean somatic embryos until 63 days treatment. Unfortunately, there are no reports concerning the effect of this antibiotic combination on somatic embryogenesis, but it was demonstrated that this association stimulates organogenesis in Pinus pinea (HumARA and OrdÁs, 1999) and Prunus armeniaca (Burgos and AlburquerQue, 2003).

Antibiotic treatments with cefotaxime alone or in combination with vancomycin proved to be highly toxic for soybean embryogenic tissues cultured for longer times (63 or more days; Tables 1 and 2). Similar results were reported for Hordeum vulgare (MATHIAS and Mukasa, 1987), Picea sitchensis (SARMA et al., 1995) and Triticum aestioum (BHAU and WAKHLU, 2001). Antibiotic breakdown products may degrade polyribosomes, inhibit protein synthesis and disrupt the membrane permeability with the time (ZHANG et al., 1999).

\section{Effects of antibiotics on suppression of $A$. tumefaciens}

In order to determine the antibiotic regime capable of suppressing Agrobacterium during the soybean somatic embryo gene transfer procedure, proliferative tissues were submitted to the integrated bombardment and Agrobacterium transformation system. After co-culture, embryogenic clusters were transferred to antibiotics containing medium and weekly observed for the presence of bacteria. Five treatments with different antibiotics types and concentrations were tested.

Bacteria presence was detected on all clusters immediately after co-cultivation (data not shown). Fourteen days later, Agrobacterium overgrowth could be observed on all control dishes (containing antibiotic-free medium). Addition of carbenicillin to the medium, regardless to concentrations, was not effective in suppressing Agrobacterium growth (Table 3; Figure 1). Embryogenic clusters cultured on 500 or $1000 \mathrm{mg} \mathrm{L}^{-1}$ carbenicillin containing medium were totally covered with Agrobacterium 21 and 35 days after the co-culture, respectively, making impossible further observations. On the other hand, treatments with cefotaxime (500 $\left.\mathrm{mg} \mathrm{L}^{-1}\right)$ and the combination of cefotaxime $\left(250 \mathrm{mg} \mathrm{L}^{-1}\right)+$ vancomycin $\left(250 \mathrm{mg} \mathrm{L}^{-1}\right)$ were effective in suppressing Agrobacterium after 16 and 9 days, respectively (Table 3; Figure 1).

Agrobacterium recurrence is frequently observed when embryogenic clusters, visually free of contaminants, are cultured in the absence of antibiotics. To determine the optimal length of antibiotic treatment, embryogenic clusters were transferred to medium without antibiotics after 35, 49 and 63 days of treatment. Agrobacterium recurrence was observed on clusters that had been submitted to 35 days of treatment, regardless of antibiotic type and concentration (Table 3). However, the number of explants lost due to Agrobacterium overgrowth was significantly lower when the combination of cefotaxime + vancomycin was used. On the other hand, after 49 and 63 days of treatment, none of the embryogenic clusters presented Agrobacterium recurrence at all antibiotics tested.

Table 3. Effect of different antibiotic treatments on suppression of LBA4404 Agrobacterium tumefaciens strain on soybean somatic embryogenic clusters

\begin{tabular}{|c|c|c|c|c|c|}
\hline \multirow{3}{*}{ Antibiotics } & \multirow{3}{*}{ Concentrations } & \multirow{3}{*}{$\begin{array}{c}\text { Days to suppress }\left({ }^{1}\right) \\
\text { Agrobacterium } \\
(\text { mean } \pm \text { SD) }\end{array}$} & \multicolumn{3}{|c|}{$\begin{array}{l}\text { Embryogenic clusters with Agrobacterium } \\
\text { recurrence after treatment }\end{array}$} \\
\hline & & & \multicolumn{3}{|c|}{ Treatment period } \\
\hline & & & 35 days & 49 days & 63 days \\
\hline \multicolumn{3}{|c|}{$\mathrm{mg} \mathrm{L}^{-1}$} & \multicolumn{3}{|c|}{$-\%$} \\
\hline Cefotaxime & 350 & $20 \pm 13 b$ & 88.9 & 0 & 0 \\
\hline Cefotaxime & 500 & $16 \pm 13 a, b$ & 88.9 & 0 & 0 \\
\hline Carbenicillin & 500 & overgrowth & $33.4^{*}$ & 0 & - \\
\hline $\begin{array}{l}\text { Cefotaxime } \\
+ \text { vancomycin }\end{array}$ & $250+250$ & $9 \pm 8$ a & - & - & - \\
\hline Control & - & overgrowth & - & - & - \\
\hline
\end{tabular}

$\left({ }^{1}\right)$ Multiple comparisons test: different letters indicate significant differences at 0.05.

* Fisher non-parametric analysis: significantly different at 0.05 . 



Figure 1. Suppression of LBA4404 Agrobacterium tumefaciens strain on soybean somatic embryogenic clusters after 30 days of different antibiotic treatments. (A) cefotaxime $350 \mathrm{mg} \mathrm{L}^{-1}$, (B) cefotaxime $500 \mathrm{mg} \mathrm{L}^{-1}$, (C) carbenicillin 500 $\mathrm{mg} \mathrm{L}^{-1}$, (D) carbenicillin $1000 \mathrm{mg} \mathrm{L}^{-1}$, (E) cefotaxime $250 \mathrm{mg} \mathrm{L}^{-1}+$ vancomycin $250 \mathrm{mg} \mathrm{L}^{-1}$ e (F) control.

Cefotaxime and carbenicillin belong to two major classes of antibiotics, cephalosporins and penicillins, respectively. These drugs, known as $\beta$ lactams, prevent bacteria proliferation by inhibiting cell wall synthesis during its division (POLLOCK et al., 1983). Both classes of antibiotics become covalently linked to the cell's penicillin-binding proteins, enzymes responsible for constructing or modifying the bacterial cell wall. Antibiotic binding prevents cell wall synthesis and provokes the death of the bacteria by cell wall lysis (NAUERBY et al., 1997). Some bacteria containing b-lactamases can prevent the activity of the antibiotics by hydrolising the cyclic amide bonds of the $\beta$-lactam ring in penicillins and cephalosporins. Cefotaxime and carbenicillin are very active antibiotics against a large number of bacteria species. However, while cefotaxime is highly resistant, carbenicillin is sensitive to b-lactamases produced by Agrobacterium (TANG et al., 2000). In addition, carbenicillin is acidlabile (Pollock et al., 1983).

Our results showed that cefotaxime is better than carbenicillin for eliminating Agrobacterium from soybean somatic embryo clusters, what can be accounted to the antibiotics features above described. Cefotaxime was previously reported as the most effective antibiotic at supressing LBA4404 Agrobacterium strain from explants of Nicotiana tabacum (Shackelford and Chlan, 1996) and Fragaria vesca (Alsheikh et al., 2002).
Vancomycin is a glycopeptide antibiotic, effective against most Gram-positive bacteria. When used in combination with a $\beta$-lactam antibiotic, vancomycin proves to be effective against Gram-negative bacteria such as Agrobacterium, since the $\beta$-lactam antibiotic disrupts the outer membrane of the bacteria allowing vancomycin to reach the bacterial cell wall and inhibit its synthesis (Burgos and Alburqueroue, 2003). Although, there were no marked differences at Agrobacterium suppression between treatments containing cefotaxime alone or in association with vancomicyn, the antibiotics combination was faster and more effective. Moreover, addition of vancomycin allowed the use of a lower concentration of cefotaxime, thereby minimizing the toxic effects of this antibiotic to plant cells on short termcultures (Table 1).

Development of an effective Agrobacteriumtransformation system for soybean depends on the availability of tissue culture techniques that permit efficient DNA delivery, selection of transformed cells and recovery of whole transgenic plants. Therefore, choice of optimal antibiotic treatment for Agrobacterium suppression is critical for transformation success. Our results indicated that, besides of efficiently eliminating bacteria, combination of cefotaxime $\left(250 \mathrm{mg} \mathrm{L}^{-1}\right)+$ vancomycin $\left(250 \mathrm{mg} \mathrm{L}^{-1}\right)$ had no negative effect on soybean somatic embryos until 63 days of treatment. These findings are valuable for improving transformation of soybean and, even, of other grain legume species. 


\section{CONCLUSION}

By identifying the antibiotic combination of cefotaxime (250 mg L$\left.{ }^{-1}\right)$ and vancomycin $\left(250 \mathrm{mg} \mathrm{L}^{-1}\right)$ that suppressed $A$. tumefaciens with the least phytotoxic effects on embryogenic tissue, we are able to recommend it for the improvement of the soybean Agrobacterium-mediated transformation procedure.

\section{ACKNOWLEDGEMENTS}

Statistical analysis was performed by Scatter Consultors in Statistics. Research support was provided by Conselho Nacional de Desenvolvimento Científico e Tecnológico (CNPq, Brazil), Fundação de Amparo à Pesquisa do Estado do Rio Grande do Sul (FAPERGS, Brazil), Universidade do Vale do Rio dos Sinos (UNISINOS, Brazil) and Centro do Agronegócio - Casa Rural (Brazil).

\section{REFERENCES}

ALSHEIKH, M.K.; SUSO, H.-P.; ROBSON, M.; BATTEY, N.H. Appropriate choice of antibiotic and Agrobacterium strain improves transformation of antibiotic-sensitive Fragaria vesca and F. v. semperflorens. Plant Cell Reports, Berlin/Heidelberg, v.20, p.1173-1180, 2002

BAILEY, M.A.; BOERMA, H.R.; PARROTT, W.A. Genotype effects on proliferative embryogenesis and plant regeneration of soybean. In Vitro Cellular and Developmental Biology, Wallingford, v.29, p.102-108, 1993

BHAU, B.S.; WAKHLU, A.K. Effect of some antibiotics on the in vitro morphogenetic response from callus cultures of Coryphantha elephantidens. Biologia Plantarum, Amsterdam, v.44, p.19-24, 2001

BURGOS, L.; ALBURQUERQUE, N. Ethylene inhibitors and low kanamycin concentrations improve adventitious regeneration from apricot leaves. Plant Cell Reports, Berlin/ Heidelberg, v.21, p.1167-1174, 2003.

CHENG, Z.M.;SCHNURR, J.A.; KAPAUN, J.A. Timentin as an alternative antibiotic for suppression of Agrobacterium tumefaciens in genetic transformation. Plant Cell Reports, Berlin/Heidelberg, v.17, p.646-649, 1998.

COOKE, D.L.; WAITES, W.M.; LEIFERT, C. Effects of Agrobacterium tumefaciens, Erwina carotovora, Pseudomonas syringae and Xanthomonas campestris on plant tissue cultures of Aster, Cheiranthus, Delphinium, Iris and Rosa; disease development in vivo as a result of latent infection in vitro. Journal of Plant Diseases and Protection, Stuttgart, v.99, p.469-481, 1992.

COSTAMILAN, L.M.; BERTAGNOLLI, P.F. Cultivo de soja. In: XXXII REUNIÃO DE PESQUISA DE SOJA DA REGIÃO SUL, 2004 <http://www.cnpt.embrapa.br/sist-prod/soja04/ index.htm> Accessed 200528 mar.
DROSTE, A.; BODANESE-ZANETTINI, M.H.; MUNDSTOCK, E.; HU, C.Y. Susceptibility of Brazilian soybean cultivars to Agrobacterium tumefaciens. Brazilian Journal of Genetics, Ribeirão Preto, v.17, p.83-88, 1994.

DROSTE, A.; PASQUALI, G.; BODANESE-ZANETTINI, M.H. Integrated bombardment and Agrobacterium transformation system: an alternative method for soybean transformation. Plant Molecular Biology Reporter, Ottawa, v.18, p.51-59, 2000.

DROSTE, A.; LEITE, P.C.P.; PASQUALI, G.;MUNDSTOCK, E.C.; BODANESE-ZANETTINI, M.H. Regeneration of soybean via embryogenic suspension culture. Scientia Agricola, Piracicaba, v.58, p.753-758, 2001.

ESTOPÀ, M.; MARFÀ, V.; MELÉ, E.; MESSEGUER, J. Study of different antibiotic combinations for use in the elimination of Agrobacterium with kanamycin selection in carnation. Plant Cell, Tissue and Organ Culture, Amsterdam, v.65, p.211-220, 2001.

FINER, J.J.; VAIN, P.; JONES, M.W.; McMULLEN, M.D. Development of the particle inflow gun for DNA delivery to plant cells. Plant Cell Reports, Berlin/Heidelberg, v.11, p.323328, 1992.

GAMBORG, O.L.; MILLER, R.A.; OJIMA, K. Nutrient requirements of suspension cultures of soybean root cells. Experimental Cell Research, Amsterdam, v.50, p.151-158, 1968.

HAMMERSCHLAG, F.A.;ZIMMERMAN, R.H.; YADAVA, U.L.; HUNSUCKER, S.; GERCHEVA, P. Effect of antibiotics and exposure to an acidified medium on the elimination of Agrobacterium tumefaciens from apple leaf explants and on shoot regeneration. Journal of the American Society of Horticultural Science, Alexandria, v.122, p.758-763, 1997.

HIEI, Y.; OHTA, S.; KOMARI, T.; KUMASHIRO, T. Efficient transformation of rice (Oryza sativa L.) mediated by Agrobacterium and sequence analysis of the boundaries of the T-DNA. The Plant Journal, Boston, v.6, p.271-282, 1994.

HOLFORD, P.; NEWBURY, H.J. The effects of antibiotics and their breakdown products on the in vitro growth of Antirrhinum majus. Plant Cell Reports, Berlin/Heidelberg, v.11, p.93-96, 1992.

HOOYKAAS, P.J.J.; MELCHERS, L.S.; RODENBURG, K.W.; TURK, S.C.H. The Agrobacterium Virulence System. In: HERMANN, R.G.; LARKINS, B. (Eds.). Plant Molecular Biology, New York: Plenum press, 1991, v.2, p.193-204.

HORSCH, R.B.; FRY, J.E.; HOFFMAN, N.L.; EICHHOLTZ, D.; ROGERS, S.G.; FRALEY, R.T. A simple and general method for transferring genes into plants. Science, Washington, v.227, p.1229-1231, 1985.

HUMARA, J.M.; ORDÁS, R.J. The toxicity of antibiotics and herbicides on in vitro adventitious shoot formation on Pinus pinea L. cotyledons. In Vitro Cellular and Developmental Biology, Wallingford, v.35, p.339-343, 1999.

LIN, J.J.; ASSAD-GARCIA, N.; KUO, J. Plant hormone effect of antibiotics on the transformation efficiency of plant tissues by Agrobacterium tumefaciens cells. Plant Science, Amsterdam, v.109, p.171-177, 1995. 
MATHIAS, R.J.; BOYD, L.A. Cefotaxime stimulates callus growth, embryogenesis and regeneration in hexaploid bread wheat (Triticum aestivum L. EM Thell). Plant Science, Amsterdam, v.46, p.217-223, 1986.

MATHIAS, R.J.; MUKASA, C. The effect of cefotaxime on the growth and regeneration of callus from four varieties of barley (Hordeum vulgare L.). Plant Cell Reports, Berlin/Heidelberg, v.6, p.454-457, 1987.

MAYOLO, G.A.; MAXIMOVA, S.N.; PISKAK S.; GUILTINAN, M.J. Moxalactam as a counter-selection antibiotic for Agrobacterium-mediated transformation and its positive effects on Theobroma cacao somatic embryogenesis. Plant Science, Amsterdam, v.164, p.607-615, 2003.

MIHALJEVIC, S.; PERIC, M.; JELASKA, S. The sensitivity of embryogenic tissue of Picea omorika (Panc.) Purk. to antibiotics. Plant Cell, Tissue and Organ Culture, Dordrecht, v.67, p.287-293, 2001.

MURASHIGE, T.; SKOOG, F. A revised medium for rapid growth and bioassays with tobacco tissue cultures. Physiologia Plantarum, Lund, v.15, p.473-498, 1962.

NAKANO, M.; MII, M. Antibiotics stimulate somatic embryogenesis without plant growth regulators in several Dianthus cultivars. Plant Physiology, Hanover, v.141, p.721725, 1993.

NAUERBY, B.; BILLING, K.; WYNDAELE, R. Influence of the antibiotic timentin on plant regeneration compared to carbenicillin and cefotaxime in concentrations suitable for elimination of Agrobacterium tumefaciens. Plant Science, Amsterdam, v.123, p.169-177, 1997.

POLLOCK, K.; BARFIELD, D.G.; SCHIELDS, R. The toxicity of antibiotics to plant cell cultures. Plant Cell Reports, Berlin/ Heidelberg, v.2, p.36-39, 1983.

RANCH, J.P.; OGLESBY, L.; ZIELINSKI, A.C. Plant regeneration from embryo-derived tissue cultures of soybeans. In Vitro Cellular and Developmental Biology, Wallingford, v.21, p.653-658, 1985.
SARMA, K.S.; EVANS, N.E.; SELBY, C. Effect of carbenicillin and cefotaxime on somatic embryogenesis of Stika spruce (Picea sitchensis (Bong.) Carr.). Journal of Experimental Botany, Oxford, v.292, p.1779-1781, 1995.

SHACKELFORD, N.J.; CHLAN, C.A. Identification of antibiotics that are effective in eliminating Agrobacterium tumefaciens. Plant Molecular Biology Reporter, Ottawa, v.14, p.50-57, 1996.

SILVA, J.A.T.; NHUT, D.T.; TANAKA, M.; FUKAI, S. The effect of antibiotics on the in vitro growth response of chrysanthemum and tobacco stem transverse thin cell layer (tTCLs). Scientia Horticulturae, Amsterdam, v.97, p.397-410, 2003.

STAFFORD, H.A. Crown gall disease and Agrabacterium tumefaciens: a study of the history, present knowledge, missing information and impact on molecular genetics. The Botanical Review, New York, v.66, p.99-118, 2000.

TANG, H.; REN, Z.; KREZAL, G. An evaluation of antibiotics for the elimination of Agrobacterium tumefaciens from walnut somatic embryos and for the effects on the proliferation of somatic embryos and regeneration of transgenic plants. Plant Cell Reports, Berlin/Heidelberg, v.19, p.881-887, 2000.

WRIGHT, M.S.; LAUNIS, K.L.; NOVITZKY, R.; DUESIING, J.H.; HARMS, C.T. A simple method for the recovery of multiple fertile plants from individual somatic embryos of soybean [Glycine max (L.) Merrill]. In Vitro Cellular and Developmental Biology, Wallingford, v.27, p.153-157, 1991.

YU, T.A.; YEH, S.D.; YANG, J.S. Effects of carbenicillin and cefotaxime on callus growth and somatic embryogenesis from adventitious roots of papaya. Botanical Bulletin of Academia Sinica, Nankang, v.42, p.281-286, 2001.

ZHANG, Q.; WISKICH, J.T.; WOOLE, K.I. Respiratory activities in chloramphenicol-treated tobacco cells. Physiologia Plantarum, Lund, v.105, p.224-232, 1999. 